\title{
Teachable Moments
}

Picture books carry wonderful opportunities for learning as well as entertainment! Listening to these books read aloud builds vocabulary (so that children understand new words when they encounter them again) and grammar (the syntax of how words and sentences go together). Examining illustrations develops viewing skills and builds context that often helps with decoding words. These skills and strategies are important to ongoing reading and writing development. But shared reading does more than teach. Interesting content also inspires a love of reading.

Many picture books are terrific sources of information - in addition to telling powerful stories - and present contexts for topics that many adults may find difficult to introduce, such as the loss of a loved one, changing family structures, or social justice themes like homelessness and racism. Picture books can be trusted to start these conversations in simple but effective ways. In this chapter, we summarise some of the Canadian picture books published in our three-year-window that work particularly well towards teachable moments that parents, caregivers or teachers might be seeking, along with developing engagement in a process that will hopefully support lifelong reading! We suggest that these picture books will open the doors to many interesting and valuable conversations as well as great life lessons.

Let's be totally clear about this: we are not advocating for prioritising learning above the joy of simply sharing these titles. Reading without specific educational expectations provides a great deal of incidental teaching and establishes literacy as a lifelong pleasurable pursuit. However, books are wonderful teachers, especially with additional care given to choices of literature and response activities that enhance understanding.

This chapter begins with ideas for sharing picture books with very young children. Then we look at ideas that encourage various age groups to respond to shared reading through art, drama, and creative writing, deepening the understanding of what is read. Finally, this chapter unpacks titles that are particularly good for critical literacy lessons - disrupting stereotypes, considering diverse perspectives, focusing on social and political themes, and enhancing ideas for taking action to support social justice. Rather than duplicating titles from other chapters, we have selected new titles to spotlight here - anticipating that our readers will easily connect them to other themes in the groups of books we spotlight in this guide.

(C) BEVERLEY BRENNA, RICHARD DIONNE AND THERESA TAVARES, 2021 
Where not otherwise indicated, the name of the author(s) appears first under each title, and the illustrator last. As with other chapters, we have provided target age ranges where we think these books will find their best audience, but there will be exceptions where older or younger children may enjoy reading/listening to these titles.

\section{$1 \quad$ Strategies for Sharing Picture Books with Young Children}

One of the most supportive literacy activities we can do with young children is shared reading. Families who read together, and talk about books, in a warm, fun environment, are building many skills that underpin the independent reading and writing tasks that children grow into. Classrooms, libraries and homes that offer shared reading opportunities are rich settings in which children's literacy development can flourish.

\subsection{The Importance of Reading Aloud to Children}

When children listen to books read aloud, it's like they're feasting on literacy vitamins! As children repeatedly hear new words in context, over time they add these words to their listening and speaking vocabularies. Through exposure to the language of books they also gain knowledge of sentence structures and other kinds of grammar - absorbing patterns for how words work together. People don't usually talk like books are written, in complex (or even complete!) sentences. Exposure to the language and syntax of books extends the rich oral language that children bring with them into school, setting the stage for the generous array of texts that older youth may encounter in their development.

Children who sit closely with adults and look at the illustrations are building meaning for what is being read, realising that picture cues support decoding. And if they are watching an adult track along with a finger during reading aloud, these children are being gently invited into a literacy club where rules like "English text works from left to right" and "the story goes from top to bottom" are internalised. As long as the experience of shared reading is fun and relaxed, even more importantly, children are experiencing the joy of reading which we hope will remain with them lifelong!

\section{2}

\section{The Importance of Talking about What Is Read}

In addition to listening to stories, youngsters who are actively engaged with older children or adults in talking about what is read gain many skills including confidence in forming and sharing opinions. This kind of talk can also draw attention to the building blocks of words - phonics - and little by little, gain 
knowledge about letters and their sounds that supports decoding and reading fluency later in life.

For example, as a parent finishes reading aloud a page in a story, they might say to the young child, "Hey, there's a word on this page that starts with the same sound as your name." Maybe the child can successfully guess the answer, or the adult can gently point out and celebrate the special letter. This can develop over time into talking about letter names, and rhyming words, and all sorts of important cues and conventions that underpin reading and writing. Key in all of this is that the conversations are relaxed and the shared time is fun. As soon as it takes on the feeling of "skill drills" or has the potential for the child to fail and lose confidence, it's critical to stop.

Families who experience stress during shared-reading should take a step back. Ask a teacher or a trusted friend for advice. Draw on resources from special education if you are a teacher or parent concerned about a struggling reader. Pushing children into negative space related to reading slows down a process where we all hope for success.

A valuable point to remember is that we want children to enjoy lifelong experiences with books and reading. As we share literature with young children, let's do our best to make it fun. This means selecting topics of mutual interest and planning for achievement by allowing the re-reading of familiar texts. If children have memorised a story, we can celebrate their great reading as well as encourage them to track with a finger, or point to particular words and letters.

If we have had good experiences with books in our past, let's recall what drew us in - the humour, the poignancy, the warmth, the emotion, the connectedness a book made us feel, the curiosity and hunger for information, all beautifully mixed together - and envision similar experiences for the children in our care.

\subsection{Connecting Reading and Writing}

As young children read materials of interest, it makes sense to let them process what they've read. Drawing a picture and talking about their favourite part or something they've learned are great ways to do this. As their confidence grows in sharing ideas, a connection to writing can be encouraged. Children who are emergent writers can use magic writing, or dictate something for an adult to write down.

As adults scribe a child's message, we are modelling many important skills. We are showing children that text is something a person thinks and says, written down. This is a very abstract idea that takes multiple concrete experiences to understand thoroughly. In addition, we are using common conventions - 
printing left to right, top to bottom, for example. We are showing how we form letters, and how individual letters combine to make words, and how words can go into sentences. We are putting finger spaces between words, to help us read them later. We are demonstrating punctuation as we stick in periods and exclamation marks.

When we scribe for a child, we can model saying each word slowly, stretching it like an elastic band, and then printing each sound that we hear. Again, remember to work with what children can understand, in their "zone of proximal development" - making sure they are comfortable and interested - or else switch off the activity. Online resources can be found under the heading Language Experience Approach that explains more about this method.

As children record their own message, they may follow developmental patterns of growth:

- Scribbling

- Beginning to include letter-like shapes

- Printing letters but without sound-correspondences

- Using letters and sounds to shape words that have invented spellings

- Beginning to use a mix of the above with some conventional spellings

- Using conventional spellings most of the time

All of the above stages in writing are important. Emergent writers need to be encouraged to put what they know into practice, without censure or perfectionistic frameworks. Also important is that children are writing to communicate something they know - an opinion, a fact they've read, a message they want to share with someone else.

A valuable point to remember is that we want children to enjoy lifelong experiences with writing and communicating ideas. Again, let's do our best to make it fun. This means, as with reading, selecting topics of mutual interest and planning for success by scribing for youngsters, when necessary and when children have something they want to communicate. We can also encourage independent practice where children can celebrate seeing their writing taped onto the family fridge for others to read.

\subsection{How Learning to Read and Write Are Like Learning to Swim}

Let's think about teaching reading and writing like teaching swimming. What if we kept children sitting outside the pool doing exercises? Would they have any fun if they weren't actually in the water? What if we kept telling them that they weren't swimming well enough for their age group, and compared them with other youngsters that were doing so much better... would our children want to go to the pool at all? 
By giving children access to the very best children's literature and encouraging them to enjoy it, we are keeping them in "the pool" while workbooks and isolated skills' drills take them out of the water.

By scribing for them, and letting them re-read dictated or favourite published materials, we are building confidence and fluency. By suggesting that children tell their own stories - maybe practicing forms of material they have heard - youngsters learn that we can all take part in the creation of stories. By encouraging close observation of the art work in books, interpreting the pictures and creating their own illustrations, we are building visual literacy and a lifelong appreciation for artistic creations. And by asking questions our children can answer, engaging their personal responses to what they are hearing, reading and viewing, we are telling them that they are really good at these things we call reading and writing. Should we take another trip to the library? Should we write letters or emails to Grandma? Let's cheer if their answer is a resounding YEs!

\subsection{When in Difficulty...}

Learning to read and write are difficult activities for many children. The human brain is wired for sound - in most cases prepared from birth to listen and speak. But it is not wired for text. Reading and writing are complex processes that must be learned quite painstakingly, bit by bit.

Instead of thinking our children are somehow flawed if reading and writing don't come "naturally" we need to think about first steps. Keep it light and fun. Keep it interesting. Encourage them to tell their own stories aloud, and then figure out together how to put them on paper. Play oral word games to help young children hear and manipulate the sounds that will eventually become attached to letters, creating written words. Such word games can be found online under headings like "phonemic awareness" and they involve activities like this:

- "Say the word hat. Now say the word hat but instead of a 'huh' sound, give me a 'buh' sound (bat). Good! Okay, say the word bat. Now say the word bat but instead of a 'buh' sound, give me a 'sssss' (sat)."

- "Listen to these two words, and put your hands on your head if they rhyme: bat, cat (yippee!); night, light (yahoo!); dog, elephant (good for you, I guess I couldn't trick you that time!)."

When families are concerned about children's reading and writing progress, it's important to remember that teachers are trained to support striving and reluctant readers. Special Education Teachers (sometimes called Resource Teachers or Learning Assistance Teachers) have had extra training in this area. 
Speech \& Language Pathologists are great at identifying whether underlying language problems are interfering with the literacy development of young children, and they may have programming that can help. Community programs, such as those offered by associations for people with learning disabilities, can often support families as well, whether a child has a reading/writing disability or not.

Be cautious of packaged programs that promise to carry a child to "gradelevel." These programs feel a lot like swimming outside the pool to children unless they have actual, real literature, related to the children's interests, that presents rich vocabulary and syntax in the context of literary stories and informational texts as well as abundant illustrations created through diverse media. Workbooks and fill-in-the-blank sheets are not equivalent to the performance of reading for enjoyment and information. Workbooks and fill-in-the-blank sheets are also not equivalent to the enterprise of using drawing and writing to communicate opinions, reflect, organise one's thoughts, or tell a story that a child is bursting to tell.

In addition to any of the books in previous chapters you think the children you know will like, here are summaries of a few additional "early childhood" titles from our set of Canadian books published since 2017. Full speed ahead into supporting the joy of reading wonderful stories and inhabiting vivid art.

\subsection{Teachable Moments'Book Suggestions for Younger Readers/ Listeners}

\section{Sloth at the Zoom}

Helaine Becker

and Orbie

A sloth anticipating delivery to a restful zoo accidentally finds herself at the zooooom where everybody moves at high speed. With only a small amount of text on each page, along with clever crayon-inspired illustrations, this is a super book for early readers. The quality of the language is also rich, with exciting verbs used throughout. Children may enjoy responding to the verbs by doing their own actions. For ages 3-7. 


\section{Big Words Small Stories: The Missing Donut}

Judith Henderson

and T. L. McBeth

The five stories in this book offer a great transition between typical picture book formatting and chapter books. Each plot revolves around Chris and his cat, Crat, and big juicy words are included and celebrated. T. L. McBeth's graphite-pencil digital artwork is cartoonish and eye-catching, and readers might enjoy creating their own sequels to these tales. For ages 4-8.

\section{How to Catch a Bear Who Loves to Read}

Andrew Katz,

Juliana Léveillé-Trudel

and Joseph Sherman

This is an imaginative story about the love of reading, based on a storyline about a little girl who catches a bear with books. Reading it aloud with young children can provide a great chance to reinforce the value of reading. Drawing other ways to catch a bear might be fun for everyone! For ages 3-7.

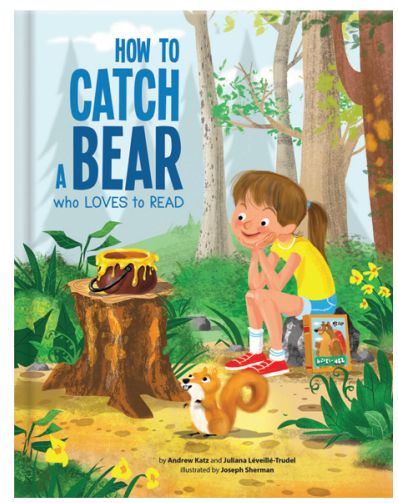

\section{The Better Tree Fort}

Jessica Scott Kerrin

and Qin Leng

With a lot of persistence and hard work, Russel and his dad build a tree fort together even though Dad is not the most experienced carpenter. When Russel discovers their neighbour's tree fort has all the bells and whistles, he learns an important lesson: there will always be a better tree fort... but not a better dad. This title might inspire discussions

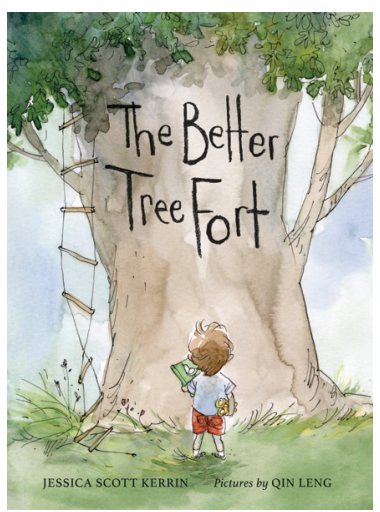
and drawings for tree house floor plans designed by other young architects. Qin Leng's alluring artwork was created with ink, watercolour, and pencil crayon. For ages $4-8$. 
Owls are Good at Keeping Secrets:

An Unusual Alphabet

Sara O'Leary

and Jacob Grant

This spectacular alphabet book combines animal facts and fiction in a way that entices children to guess what's not true, and many of the animals represent situations and feelings with which young children can identify. Children responding to this one might want to create their own alphabet books, one letter at a time. For ages 3-6.

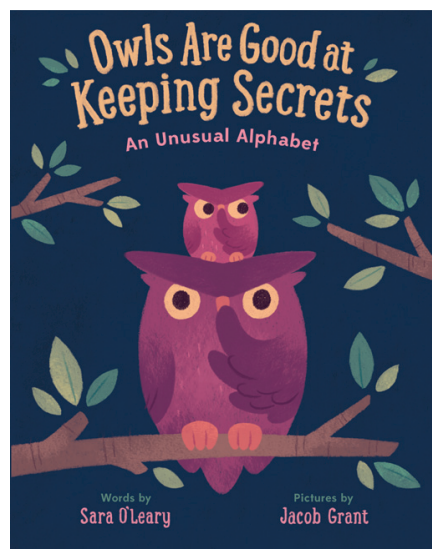

\section{Fox and Squirrel Help Out}

\section{Ruth Ohi}

Fox is immediately busy helping out a baby bat who literally drops in, and Squirrel reacts with understandable jealousy. The book's simple language might encourage shared reading, where partners take turns on alternate pages, or entice young children to read the repeated "squeaks" of the bat. For ages $2-7$.

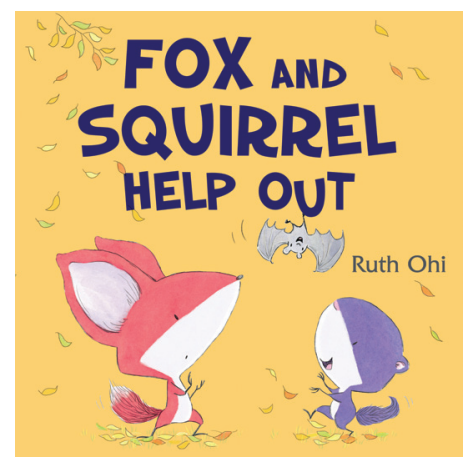

\section{Hop into Bed!}

Nicholas Oldland

This adventure relates a day in the life of Hop, a frog who loves to... hop! A reading where children respond to the verbs and mimic Hop's actions - bouncing, twisting, jumping, springing, leaping, and flopping - will encourage active vocabulary learning. Art created in Adobe Photoshop and drawn with a Wacom tablet has resulted in humorous, vibrant illustrations. For ages $3-7$.

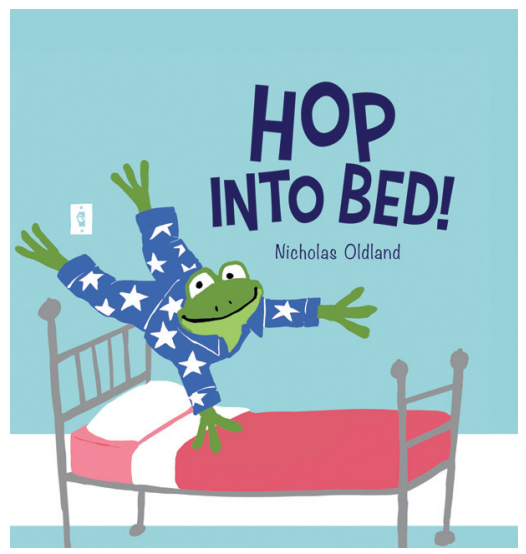




\section{Pinny in Fall \\ Joanne Schwartz \\ and Isabelle Malenfant}

This book is part of a series about the outdoor adventures of a girl and her friends. It offers a bridge between picture books and early chapter books, organised with a simple table of contents and "chapter titles" for each section. Practicing use of the table of contents to find particular sections might help children use this tool with other books. Isabelle Malenfant's use of mixed-media here includes soft pastel, graphite pencil, Q-tips, and an electric eraser. For ages $4-8$.

Reading comprehension is the goal of reading. Activities that help readers think more carefully about the characters, situations, and information in what they read deepen their understandings. Making connections to themselves, other texts, and the wider world is an important skill that children learn and improve over time. These connections can be practiced at home, in other community settings, and at school.

Dr. Louise Rosenblatt was a major theorist in literacy education and one of her contributions involved the idea that reading is a dynamic transaction between reader and text. Her work helps us understand that readers bring thoughts and feelings to what they read, and this affects what they take away from the reading.

Answering only literal comprehension questions after reading - such as "What colour was the jacket she wore?" - does not encourage readers to think deeply about what they read or to reflect upon it in the context of their own lives. Literal comprehension questions, given as tests, privilege the kinds of information valued by the creators of the test and not necessarily the kinds of information valued by the reader or prioritised in the reader's family or community. In this way, testing children on accuracy of recalled details can label them as poor readers when in fact their comprehension is good, it just doesn't match the narrow band of responses expected regarding the literal questions that were asked.

In contrast to literal comprehension, inferential comprehension (being able to "read between the lines") and personal response are important signs 
of reader understanding. They aren't easily measured by standardised tests, however, and for this reason, have often been overlooked on testing protocols.

Art, Drama and Creative Writing Activities are three categories of response that greatly support reading comprehension, according to children's literature expert Dr. Charlotte Huck. Many contemporary literacy specialists such as Nanci Atwell, Lucy Calkins, Kelly Gallagher, and Penny Kittle - rock stars of the literacy world - support the view that independent reading skills and strategies are encouraged by wide reading, interest-based reading, and follow-ups that respect children's authentic responses to what they read.

In addition to books suggested in previous chapters, here are summaries of some more titles from our set of Canadian books published between 2017 and 2019. We offer specific response activities as ideas from which to springboard. Enjoy the heights as creativity really knows no bounds! For each of the suggestions made for the books listed, the reader might instead decide on some other path to demonstrate the creative potential of reader-response. The sky is the limit!

\section{Come Back to Earth, Esther! Josée Bisaillon}

Esther is an ordinary girl who imagines her future in space. Readers can be encouraged to imagine themselves in new places, as well, creating cut-paper collage-type pictures similar to Josée Bisaillon's style. For ages $4-8$.

\section{Out of the Blue}

\section{Wallace Edwards}

Ernest meets a space creature and both are afraid. With time and patience, the two discover they have something in common and become friends who help one another. This title unfolds in comic panels as well as full-page pictures, and could inspire young artists to create a storyboard of either the beginning/ middle/end presented here, or their own creative

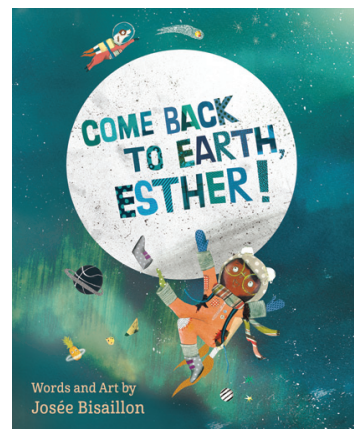
tale. For ages $3-7$. 


\section{A World of Kindness}

Ann Featherstone (editor)

Various illustrators present images of kindness in this lovely picture book that could invite readers to create their own pictures of what kindness means to them. Emergent writers could dictate sentences underneath their picture for productive re-reading. For ages $2-6$.

\section{Fox and Raccoon}

Lesley-Anne Green

From the "Juniper Hollows" series, Fox and Raccoon are good friends who help each other. Shoebox dioramas could be an art project inspired by the three-dimensional textile art in this title. For ages $3-7$.

\section{Anna at the Art Museum}

Hazel Hutchins,

Gail Herbert

and Lil Crump

Anna and her mother visit an art museum where Anna is extremely bored. However, she eventually discovers a work of art she likes, and her perspectives on the gallery change. Children might enjoy creating a piece of original art along with a reason why the gallery should acquire it for their collection. For ages $4-7$.

\section{Deep Underwater}

Irene Luxbacher

No other title would be better to motivate paintings of the undersea world than this dreamy picture book by Irene Luxbacher, whose watercolour, acrylic, and collage illustrations are truly inspirational. For ages $5^{-8}$.
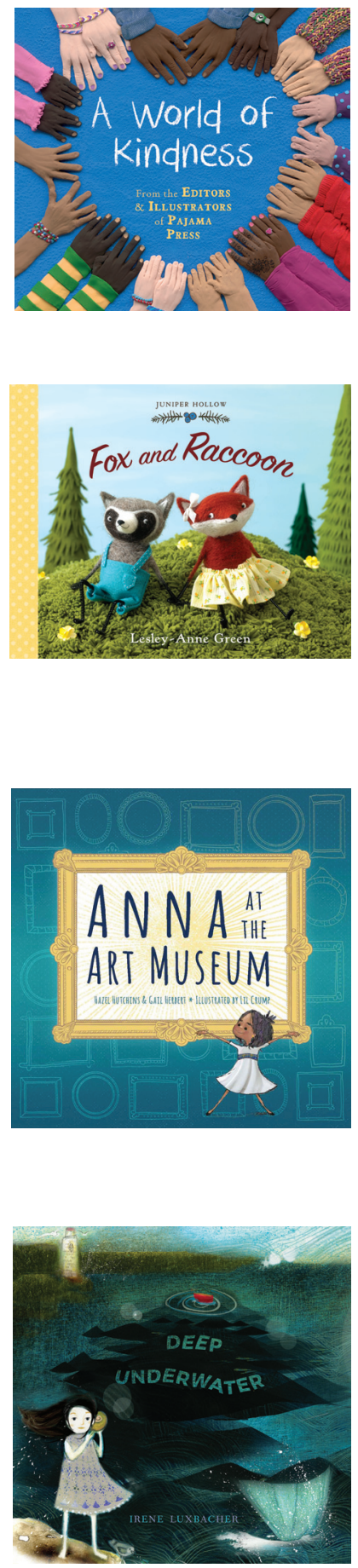


\section{Treasure}

Mireille Messier

and Irene Luxbacher

This charming book about two children searching the woods for a treasure reminds readers that the best treasures are hard to find and very personal. Children may enjoy drawing their vision of the best treasure ever. Irene Luxbacher's elaborate, dreamy mixed-media illustrations were produced using graphite, watercolour, acrylic, soft pencil crayon,

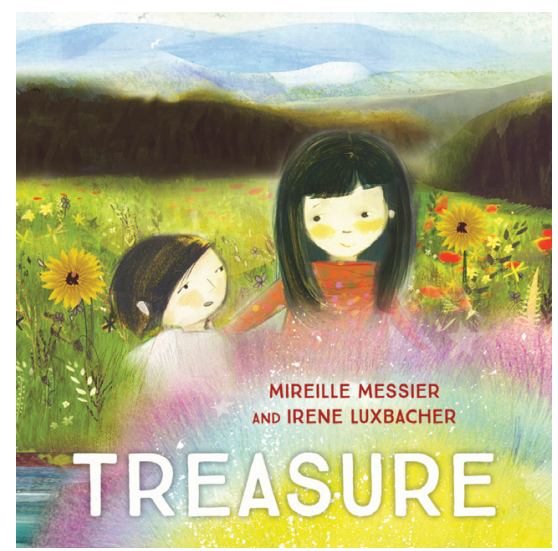
and found paper. For ages 3-8.

\section{The Clothesline}

Orbie

Here we have the creative problem of an active boy stuck on a clothesline. Solving this challenge as a puzzle, through drawing and explaining a solution, would offer great fuel for critical thinking and expressing ideas. Orbie's dramatic watercolour artwork is uncluttered and captivating. For ages $4-8+$.

\section{Sleep, Sheep! \\ Kerry Lyn Sparrow \\ and Guillaume Perreault}

Duncan dodges bedtime as best he can, until counting sheep presents him with an animal whose excuses rival his own. Children could create artistic advice to add to a "Bedtime Book for Tired Parents" - what ideas could help Duncan and other youngsters turn off the light? Guillaume Perreault's illustrations offer warmth, humour, and an illuminative use of colour. For ages $3-7$.

\section{Small in the City \\ Sydney Smith}

This poetic, visual feast for the senses depicts what it's like for one child to be small in the city. It might inspire readers to explore Sydney Smith's ink and watercolour media and present what it's like for them to be children where they live. For ages $4-8+$. 


\section{Moon Wishes}

Guy Storms,

\section{Patricia Storms}

and Milan Pavlović

This title lists all sorts of things the narrator would do "... if I were the moon." Young children can be encouraged to use watercolour or some other media to show what they would do if they were the moon. Milan Pavlović's kaleidoscopic images use mixed-media, drawing inks and colour pencils. For ages 4-7.

\subsection{Book Suggestions That Inspire Drama Activities}

\section{Caribou}

Dorothy Aglukark,

David Aglukark

\section{and Amanda Sandland}

This beautiful volume contains a wealth of facts about the caribou, along with firsthand accounts from elders Dorothy and David Aglukark, who live in the Arctic. Excellent nonfiction titles such as this one offer interesting opportunities for children to present informative soliloquys or interviews from the perspective of the focus animal. For ages 4-9.

\section{Sir Simon: Super Scarer}

\section{Cale Atkinson}

Sir Simon, a ghost, tricks Chester into doing his chores, freeing himself up for cross stitching, eating pizza, and various other activities. Children could role play how they would convince someone else to do chores they dislike and mime things they would do in their additional spare time. The richly toned, digital artwork here is witty and sweet. For ages 4-8.
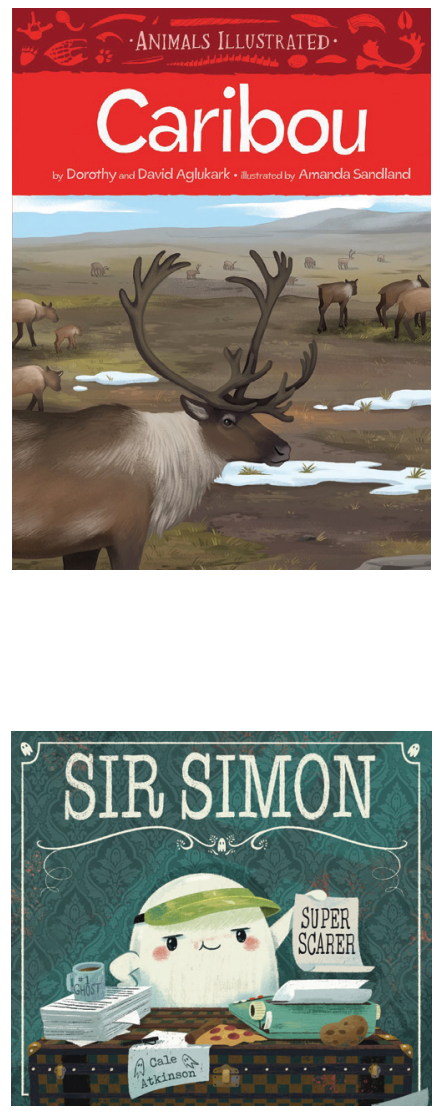


\section{Giraffe and Bird Together Again}

Rebecca Bender

Third in Rebecca Bender's series of books about two squabbling friends, this book, chock full of Bender's acrylic and coloured pencil illustrations, offers loads of rich fare for improvisation. Children can present arguments from one side or another, or create dramatic scenes of these animals in conflict... and then creating peace with one another. For ages 4-7.

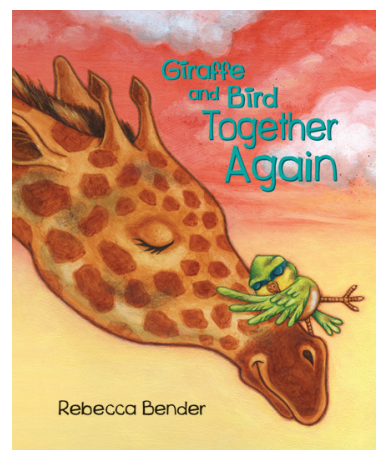

\section{You're in Good Paws \\ Maureen Fergus \\ and Kathryn Durst}

A mix-up occurs for young Leo when his parents take him to the animal hospital instead of the human hospital. Kathryn Durst's pastel and coloured pencil illustrations add to the hilarity. Children can be encouraged to "interview" various

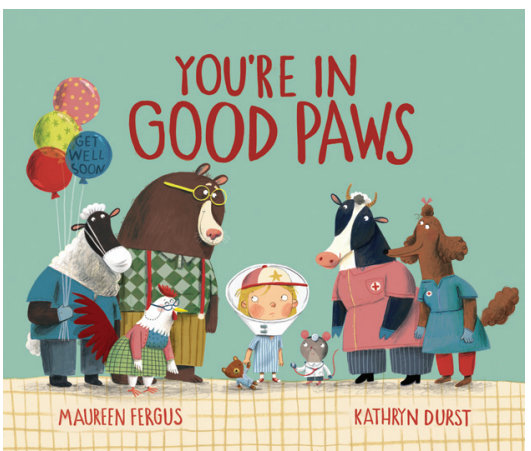
animals in the context of Leo's care, and improvise the weary parents who just want their son to get better soon, offering rich contexts for language use. For ages $4-8$.

\section{What Are You Doing, Benny? \\ Cary Fagan \\ and Kady MacDonald Denton}

This story about two siblings, enhanced by Kady MacDonald Denton's spectacular panel illustrations, lends itself to improvised scene work as children take on "big brother/little brother" dialogues. For ages $3-8$.

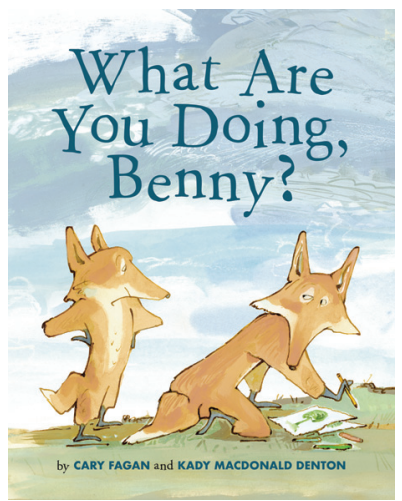




\section{Buddy and Earl Meet the Neighbors}

Maureen Fergus

and Carey Sookocheff

In this volume of the "Buddy and Earl" series, the dog characteristically wants to nap but the hedgehog wants to play superheroes saving the city, a storyline supported by Carey Sookocheff's elegant acryl gouache illustrations on watercolour paper, assembled in Adobe Photoshop. Taking this theme into imaginary play can support language development

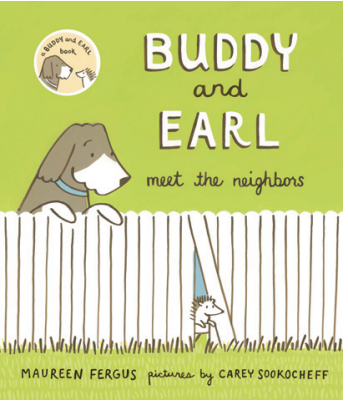
in young children. For ages 4-8.

\section{Harry's Hiccups}

Jean Little

and Joe Weissmann

In this picture book written by children's literature legend Jean Little, and marvellously illustrated by Joe Weissmann, using acrylics on board, Harry Chung has a case of the hiccups. He follows the advice of one person after another until a frog finally surprises the

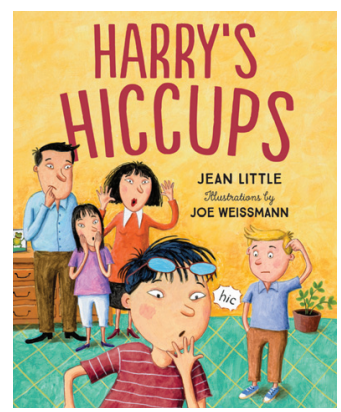
hiccups away. Children could interview others to discover various ways to get rid of hiccups, and then dramatise their favourites. For ages $4-8$.

\section{Simonie and the Dance Contest \\ Gail Matthews \\ and Ali Hinch}

This heartwarming story shows how practice - and a little inspiration - can go a long way. It is based on the annual Christmas dance contest in the community of Taloyoak, Nunavut. Groups of children

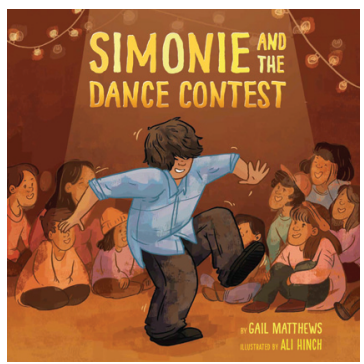
could create tableaus (frozen scenes) of contest preparation and experience. They could also improvise TV interviews of the winner, and even "hotseat" the floor itself in seeking different perspectives of the dance-off. For ages 4-9. 


\section{Nutcracker Night \\ Mireille Messier \\ and Gabrielle Grimard}

The magic of a child's visit to the ballet with her father, illustrated with watercolour, gouache, oil, coloured pencil, and digital media, is captured in a text with the full range of onomatopoeic possibilities! Creating a "soundscape" for the story, or simply chiming in with the "noisy words," will offer lots of auditory play for children listening to the tale. For ages $3-7$.

\section{No Help Wanted! \\ Ruth Ohi}

With brightly corresponding mixed-media watercolour and coloured pencil illustrations, this tale explores conflict when one child wants sole care of a school pet. Role playing among characters might work well to explore related issues and solutions

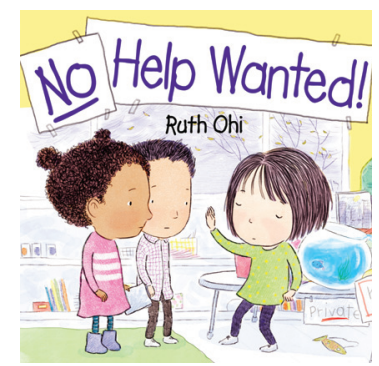
as Posey, Jacob, and Sam discuss the care of Bluey.

In addition, a character study of Bluey by "hotseating" - where a child plays Bluey and others ask him questions - might give individual children a chance to respond to information they have learned about fish, speaking from Bluey's perspective: "First I want you to remember not to overfeed me...." For ages 4-8.

\section{What Cats Think}

John Spray

and Mies van Hout

The many facets of a cat's personality are celebrated here. Capricious free verse from author John Spray pairs with Mies van Hout's striking acrylic ink, oil pastel and gouache illustrations. Evocative vocabulary in bold text may inspire elegant mime as young children can be encouraged to portray these words with their

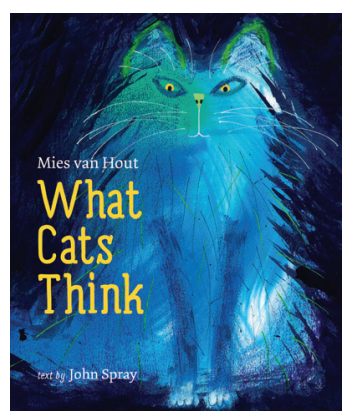
faces and bodies. For ages $5-9$. 


\subsection{Book Suggestions that Inspire Creative Writing Activities}

\section{Unicorns 101}

Cale Atkinson

This creatively zany picture book contains everything everyone always wanted to know about unicorns. It could inspire book-making on all sorts of creatures made-up, of course! For ages $5^{-10}$.

\section{Little Brothers \& Little Sisters}

Monica Arnaldo

This book celebrates the negatives and positives of having an older sibling. Children could respond by creating lists of benefits and drawbacks for various family positions: an only child, the eldest child, a child in the middle, or the youngest child. For ages $4-7$.

\section{The Pencil}

Susan Avingaq,

Maren Vsetula

and Charlene Chua

Susan loves watching Anaana write letters to people in other camps. Anaana has one precious pencil, and she keeps it safe in her box for special things... until Anaana is away help-

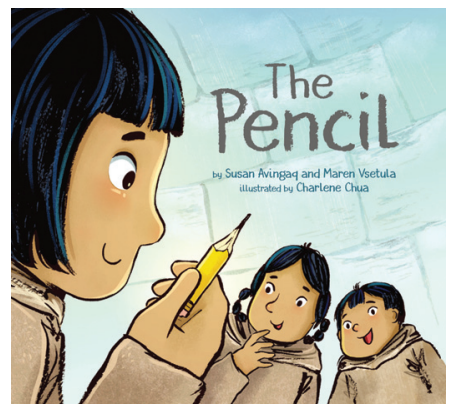
ing a neighbour and Ataata brings out the pen-

cil! This story is about the importance of using things wisely. Researching the origins of pencils, and creating pencil pamphlets (in pencil, of course!), might inspire youngsters to think about the history of common objects. For ages $3-8$. 


\section{If a Horse Had Words}

Kelly Cooper

and Lucy Eldridge

This engaging book, illustrated in dramatic watercolour, is a celebration of the friendship between a boy and a horse. Written in simple, evocative text that suggests key words from the horse's perspective, it offers a great opportunity for young writers to create their own wordlists pertinent to other animals. For example, a puppy's list might include: SHOES, PARK, and

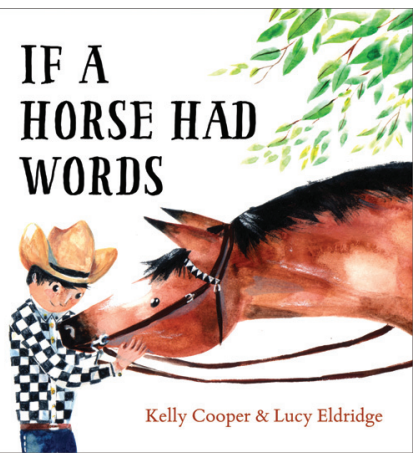
BLANKET. For ages 4-8.

\section{Hotel Fantastic}

Thomas Gibault

From superheroes and dragons to monsters and aliens, everyone is welcome at this hotel, and the suits are designed to meet everyone's needs - depicted through cinematic, digital illustrations. A twist at the end reveals the vivid imagination of one child, and others can be invited to create their own spectacular guest house. For ages $3-8$.

\section{The Magician's Secret}

Zachary Hyman

and Joe Bluhm

Charlie is transported into his grandpa's adventures through a collection of objects in an old trunk, illustrated with Joe Bluhm's fantastical digital artwork. Children can be offered a range of objects to choose from, and write their own escapades. For ages $5^{-9}$.

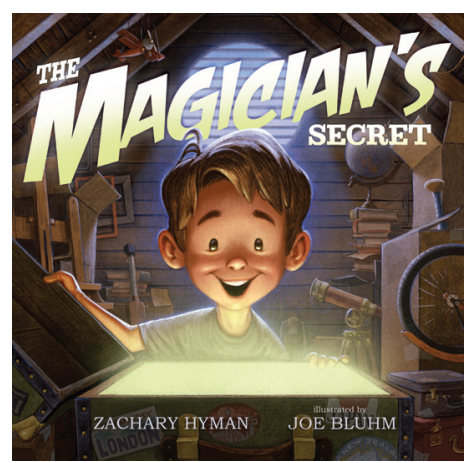




\section{The Bagel King}

Andrew Larsen

and Sandy Nichols

Eli's grandfather treats his grandson to bagels and cream cheese every Saturday. But when Zaida has an accident and needs to rest, Eli must find a way to treat him in return, a story vividly illustrated in delicious-looking acrylics. Young writers can list other ways to help Zaida, or note things they themselves have done to assist people in need. For ages 4-8.

\section{Emma's Gems}

Anne Renaud

and Leanne Franson

Emma's grandfather carries three stones in one of his pockets. Each day, as he carries out three acts of kindness - one for a person, one for an animal, and one for the planet - the stones change pockets, a story stylishly illustrated by Leanne Franson with ink and watercolour. Children can experiment with stones of their own, keeping a diary of the helpful tasks completed each day. For ages 4-8+.

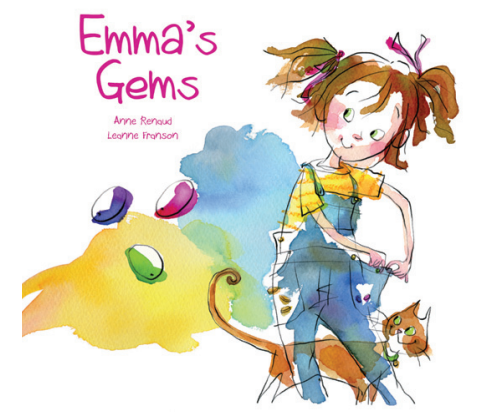

\section{Gargantua (Jr!): Defender of Earth}

Kevin Sylvester

A young Godzilla-like narrator wants to grow up to be just like Mom. This title, brightly illustrated with pencil, pen and ink on Bristol board, with finishing and colour added in Adobe Photoshop, can inspire older readers to create parallel stories based on other fictional monsters (and their families). For ages $4-8$. 


\section{Always With You \\ Eric Walters \\ and Carloe Liu}

Emily's grandfather has passed away, but he leaves her a series of letters - appearing as pop-out letters within this book - that she opens over time. Children can be encouraged to create letters of their own to connect with loved ones or even for their older selves. For ages $5^{-9+}$.

\section{Dog vs. Ultra Dog \\ Troy Wilson \\ and Clayton Hanmer}

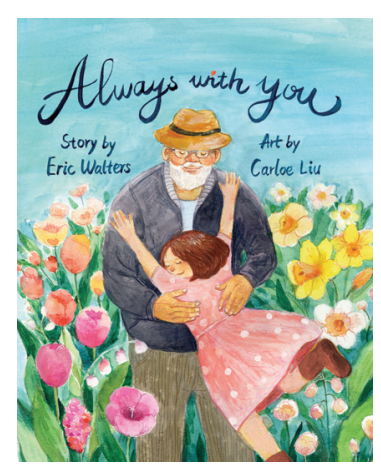

When Tim becomes obsessed with a superhero, his dog jealously tries to win his attention. This title uses a number of graphic novel conventions that might inspire young writers to pen their own pet-inspired stories with speech bubbles, thought bubbles, and narration as well as comic-style illustrations. For ages $5^{-8}$.

\section{Alfie, No! \\ Frieda Wishinsky \\ and Emma Pedersen}

This captivating title is the story of a boy and his dog that both get dirty playing, with highly engaging illustrations in gouache on cold pressed watercolour paper. Its surprise ending tells us that the narrator is actually the dog. Children might enjoy dictating or writing their own stories from the point of view of

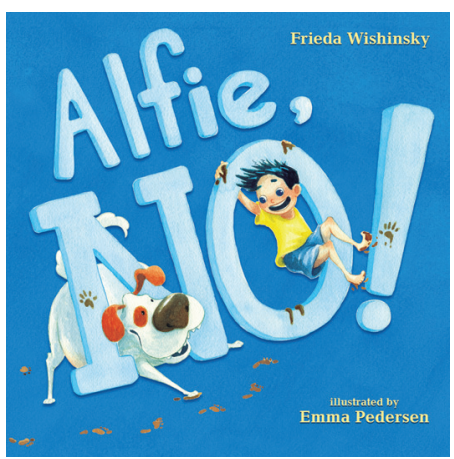
a real or imagined pet. For ages 4-8.

Some adults might suggest that critical literacy lessons are the most important teachings of all in order to help young readers grow up to be positive changemakers. In addition, we think about critical literacy as a skill that also motivates 
reading and writing, as children realise the impact of words on themselves, their peers and families, and the wider world around them.

We see critical literacy lesson as disrupting the commonplace - helping children unpack stereotypes in what they read. We also believe these lessons will help young readers consider multiple perspectives - an important skill when working with other people - focusing on socio-political themes important to the ongoing wellbeing of Planet Earth and its occupants. We also suggest that critical literacy is one way of taking action to support social justice - talking about what is right and wrong, good and bad, and then figuring out ways to improve things as best we can.

In addition to applying critical listening, reading, and viewing strategies to books previously listed in this text, the following section has titles listed with examples of critical literacy lessons, although learning can also occur very nicely through diverse reading without direct follow-up.

\section{A Cage Went in Search of a Bird}

Cary Fagan

and Banafsheh Erfanian

This story is based upon an aphorism by Franz Kafka and follows themes of belonging and friendship, accompanied by luxurious acrylic and oil illustrations. Readers can discuss characteristics they look for in a friend, and consider how other objects might be re-purposed to save the environment. For ages $4-8$.

\section{Little Blue Chair \\ Cary Fagan \\ and Madeline Kloepper}

A chair embarks on a journey from one occupant to another, with vintage ink and pencil illustrations extending additional details. Readers can think further about reusing and recycling possessions of their own. For ages 4-8.
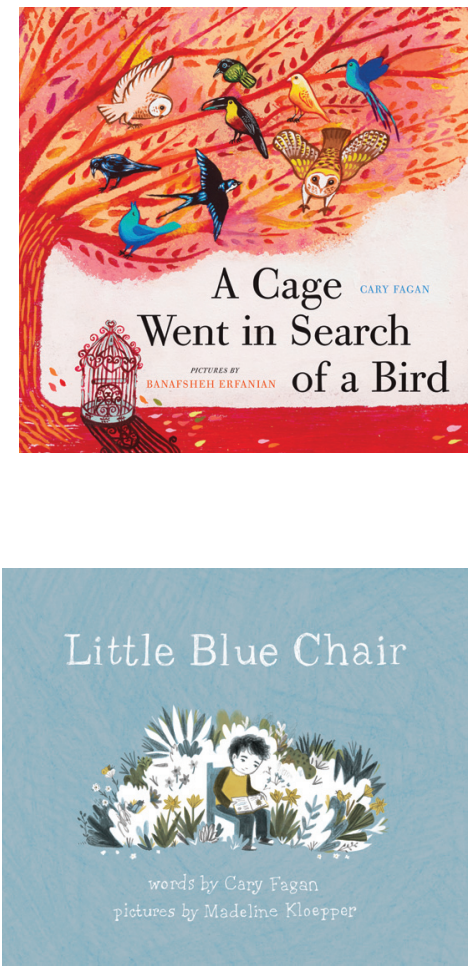


\section{The Day Dad Joined My Soccer Team \\ Maureen Fergus \\ and Mike Lowery}

This timely story presents a father who volunteers to help out with his son's soccer team and competitively jumps into the game. His son very responsibly teaches him some rules about parenting as well as coaching, leading to good lessons for helicopter parents tempted to interfere with their own children's activities, as well as good lessons, for everyone, about respect. Mike Lowery's comic-esque Adobe Photoshop illustrations pay attention to many engaging details. For ages $4-8+$.

\section{Buddy and Earl Go to School \\ Maureen Fergus \\ and Carey Sookocheff}

Buddy, the dog, and Earl, the hedgehog, spend an entertaining day at school where Earl unexpectedly becomes the teacher. Acryl gouache illustrations engage and enhance. There is an interesting theme here about achievement depending on the rela-

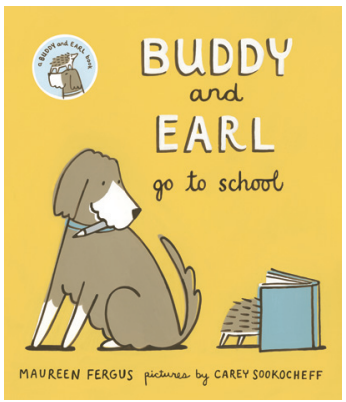
tionship between what is taught and the learner, as Buddy excels at Earl's lessons. Questions for older students about who decides school curriculum could naturally follow. For ages $4-9^{+}$.

\section{Hand over Hand}

Alma Fullerton

and Renné Benoit

Nina wants to fish but her grandfather discourages her: "A boat is not the place for a girl." Various messages to identify include: girls can succeed in areas stereotypically associated with boys; be self-sufficient; follow your dreams; ask for help when you need it. In addition, the full storyline as Grandfather changes his mind is a powerful example of growth, extended by Benoit's eye-catching illustrations in coloured pencil and watercolour. For ages 4-8+. 


\section{What Happens Next}

Susan Hughes

and Carey Sookocheff

This picture book focuses on a child's experiences of being bullied at school, simply yet poignantly illustrated in acryl gouache. While the narrator's difficult situation is resolved in the story, children can be encouraged to talk about whether they think this would happen in real life. Through discussions after reading the book, alternative ideas for supporting victims and facing bullies can flourish. For ages 6-10+.

\section{Encounter}

Brittany Luby

and Michaela Goade

Fisher and Sailor meet on local soil in 1534, but what if things had been quite different? This spectacular picture book, illustrated in digital and mixed-media, involves a re-writing of his-

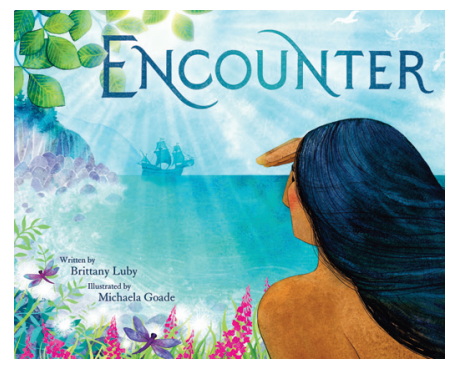
tory by two Indigenous creators. Brittany Luby, of Anishinaabe descent, is a historian at the University of Guelph; Michaela Goade, of Tlingit descent, is a designer and illustrator living in Alaska. Questions for young readers include: "How does this story differ from historical accounts about the Jacques Cartier expedition to what is now known as North America?" and "What does this story help us understand?" For ages 7-10.

\section{The Fog}

Kyo Maclear

and Kenard Pak

This dreamy picture book offers a metaphor for environmental awareness as two friends become concerned about the increasing fog around their island. Readers could be encouraged to think about how "the fog" could actually be any social justice issue to which the author is nudging us to attend. For ages 4-12.

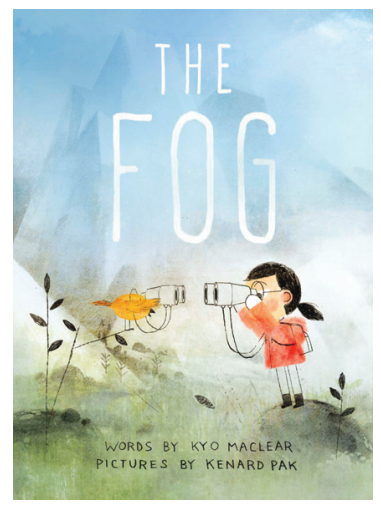




\section{Moving Day! \\ Robert Munsch \\ and Michael Martchenko}

This exuberant story, accompanied by emotive watercolour, pencil, and digital media, covers a moving day where Danielle is asked to help pack... and subsequently puts her siblings in boxes. While all in good fun here, readers can be asked to examine the actions of parents and children and describe their own moving day ideas where things run a little more smoothly. For ages 3-8.

\section{Princess Puffybottom... and Darryl \\ Susin Nielsen \\ and Olivia Chin Mueller}

An age-old story about a pampered cat who is annoyed when a cute puppy arrives on the scene, this title has a contemporary twist along with lavish, digital illustrations. The pet owners, soon to bring home a new baby, are a same-sex couple. Older readers might be encouraged to think about how this book fills some gaps in stories about families. For ages $4-8$.
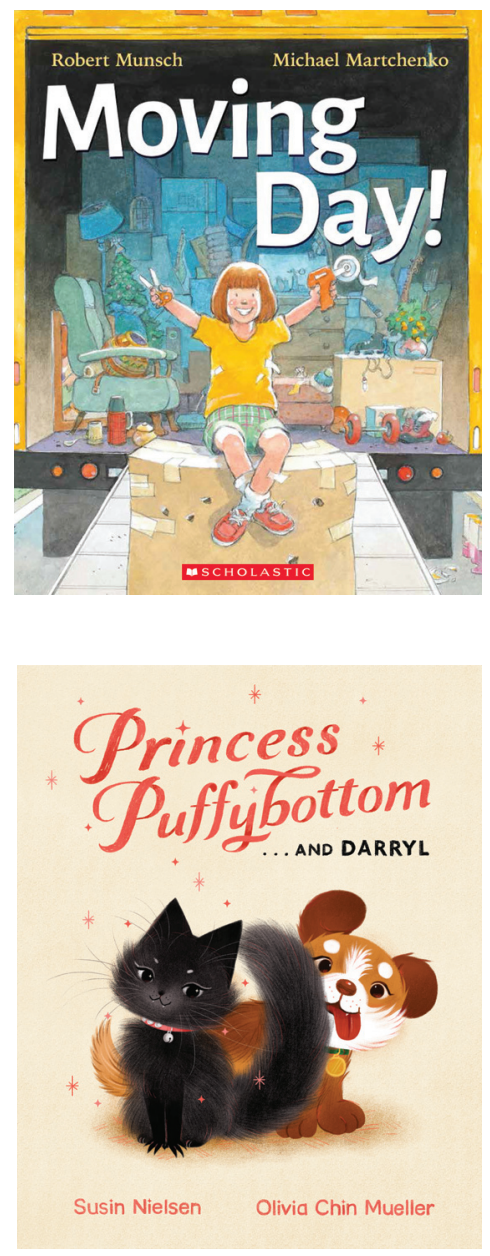

\section{The House at the End of the Road}

Kari Rust

Three children vandalise an old house and confess their actions to Grandma. When they return to apologise, they meet an old man who was once their grandma's favourite teacher and they visit him all summer. When Mr. Peterson is suddenly moved into a retirement house, the young people long to do something nice for him... and eventually create a care parcel with photos of his old digs. Discussions of this book could lead into conversations about ageism, impulsivity, and personal agency. For ages $5^{-8+\text {. }}$ 
Town Is by the Sea

Joanne Schwartz

and Sydney Smith

Set in 1950s Cape Breton, this story depicts the legacy of a mining town through the eyes of a young boy who will no doubt follow his father underground. Illustrations by Sydney Smith will enchant audiences with their blend of muted watercolour, ink, and gouache. Readers will be inspired to think about choice and agency, as well as environmental law and worker safety. For ages $5^{- \text {adult. }}$

\section{You Hold Me Up}

Monique Gray Smith

and Danielle Daniel

This beautiful book presents different ways people help one another. It can be a simple story about friendship, or a complex metaphor for entire countries. Author Monique Gray Smith has Cree and Lakota ancestry while illustrator Danielle Daniel - who has created bold and sensitive images for this

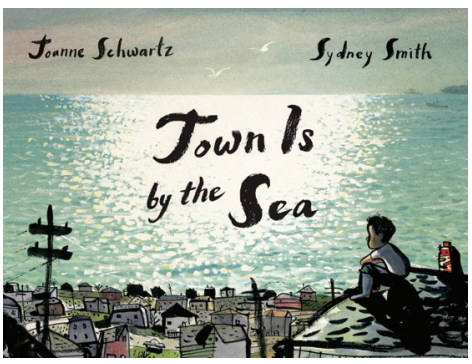
book, using gouache, acrylic, and pencil - is Métis. There is also another version of this book available in Plains Cree and English, translated by Mary Cardinal Collins. For ages $3-8+$.

\section{The Couch Potato}

\section{Kerry Lyn Sparrow}

and Yinfan Huang

Mr. Russet, a stay-at-home dad, can't keep up with his family's clutter so he goes on strike. In the spirit of The Little Red Hen and other traditional tales, he finally fries up the living-room potato into a glorious snack that no one else wants to eat... so he enjoys it himself. The images, in coloured pencil, gouache, and watercolour, are hilarious. Conversations about ways to divide chores in busy families, as well as Dad's role as home-maker, might arise from this one. For ages $4-8$. 


\section{Fairy Science \\ Ashley Spires}

A fairy named Esther pits magic against science to save a tree, a storyline presented in engaging prose and mesmerising digital illustrations. Discussions for older readers about women in science, as well as how to determine what is fact in contemporary media, are both topics worthy of air time. For ages 4-8.

\section{Nibi's Water Song}

Sunshine Tenasco

and Chief Lady Bird

A young girl's powerful voice enlists others to stand together in support of fresh water for her community and beyond. An afterword presents a call to action in relation to the many Indigenous communities in Canada without access to clean water. Author Sunshine Tenasco is Anishinabe and a clean water activist. Chief Lady Bird is a Chippewa and Potawatomi artist from Rama First Nation and Moose Deer Point First Nation, and her inspiring illustrations here were created digitally. For ages 4-10+.

\section{Sugar and Snails}

Sarah Tsiang

and Sonja Wimmer

This picture book unpacks the gender stereotype that depicts girls as "sugar and spice" and boys as "frogs and snails." Readers can be encouraged to consider books and other media that propagate or challenge gender stereotypes, and interrogate the messaging they hear in their communities. For ages 4-8.
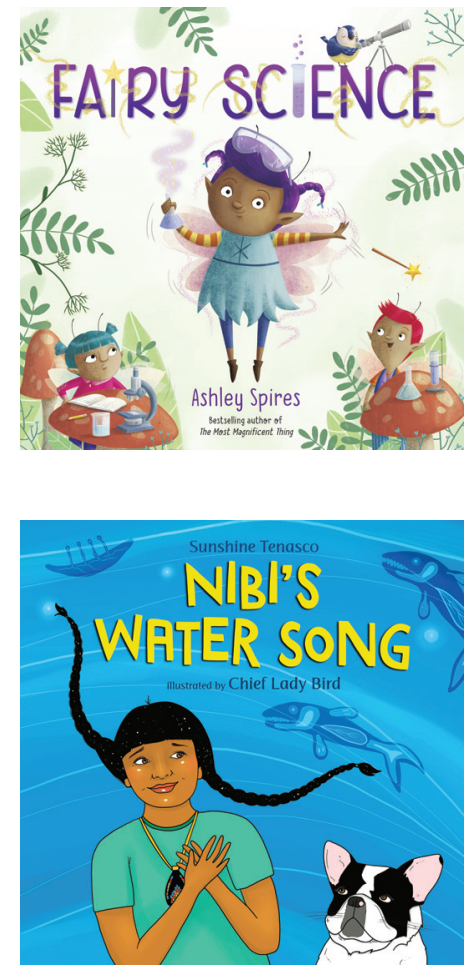


\section{Blue Rider \\ Geraldo Valério}

A city wakes, a young girl glimpses the morning, and goes outside into a crowd. In this wordless picture book, the young girl finds a book with a beautiful blue horse on the cover. Her imagination takes flight as the horse gallops into episodes of colour that continue to spill from the girl's memory when she returns home. Geraldo Valério was

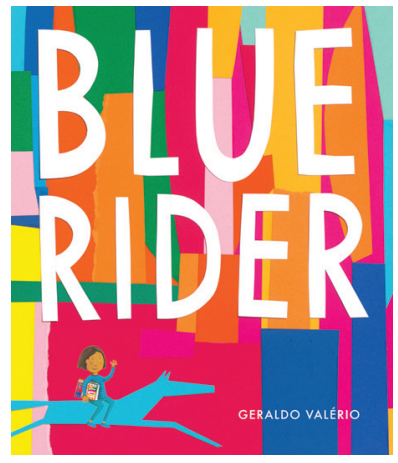
inspired by the German Expressionist group Der Blaue Reiter, and his images here demonstrate how art can transform the everyday. Audiences can talk about the therapeutic power of art. For ages 3-10+.

\section{Great Job, Mom! \\ Holman Wang}

Paired with Great job, Dad! this story dislodges gender stereotypes by describing what two parents do as occupations, and for love. Mom, for example, is employed as a carpenter but at home she has many other roles. A "behind the scenes" section at the back of the book offers information on the creation of Wang's unique, needle-felted 3 D illustrations. For ages $4-7$.

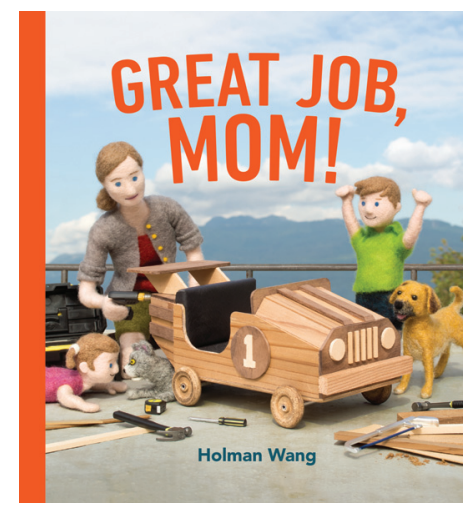

\section{Bibliography}

*In the spirit of the recommendations of the Truth and Reconciliation Commission, an asterisk appears beside works created by Indigenous writers or artists.

*Aglukark, Dorothy \& Aglukark, David (illustrated by Amanda Sandland) (2019). Caribou. Iqaluit, NU: Inhabit Media.

Arnaldo, Monica (2018). Little Brothers \& Little Sisters. Toronto, ON: Owlkids Books.

Atkinson, Cale (2019). Unicorns 101. Toronto, ON: Tundra Books/Penguin Random House.

Atkinson, Cale (2018). Sir Simon: Super Scarer. Toronto, ON: Tundra Books/Penguin Random House. 
*Avingaq, Susan \& Vsetula, Maren (illustrated by Charlene Chua) (2019). The Pencil. Iqaluit, NU: Inhabit Media.

Becker, Helaine (illustrated by Orbie) (2018). Sloth at the Zoom. Toronto, ON: Owlkids Books.

Bender, Rebecca (2018). Giraffe and Bird Together Again. Toronto, ON: Pajama Press. Bisaillon, Josée (2019). Come Back to Earth, Esther! Halifax, NS: Nimbus Publishing. Cooper, Kelly (illustrated by Lucy Eldridge) (2018). If a Horse Had Words. Toronto, ON: Tundra Books/Penguin Random House.

Edwards, Wallace (2018). Out of the Blue. Toronto, ON: North Winds Press/Scholastic Canada.

Fagan, Cary (illustrated by Banafsheh Erfanian) (2017). A Cage Went in Search of a Bird. Toronto, ON: Groundwood Books/House of Anansi Press.

Fagan, Cary (illustrated by Kady MacDonald Denton) (2019). What Are You Doing, Benny? Toronto, ON: Tundra Books/Penguin Random House.

Fagan, Cary (illustrated by Madeline Kloepper) (2017). Little Blue Chair. Toronto, ON: Tundra Books/Penguin Random House.

Featherstone, Anne (Ed.) (2018). A World of Kindness. Toronto, ON: Pajama Press.

Fergus, Maureen (illustrated by Carey Sookocheff) (2017). Buddy and Earl Go to School. Toronto, ON: Groundwood Books/House of Anansi Press.

Fergus, Maureen (illustrated by Carey Sookocheff) (2018). Buddy and Earl Meet the Neighbors. Toronto, ON: Groundwood Books/House of Anansi Press.

Fergus, Maureen (illustrated by Kathryn Durst) (2019). You're in Good Paws. Toronto, ON: Tundra Books/Penguin Random House.

Fergus, Maureen (illustrated by Mike Lowery) (2018). The Day Dad Joined My Soccer Team. Toronto, ON: Kids Can Press.

Fullerton, Alma (illustrated by Renné Benoit) (2017). Hand over Hand. Toronto, ON: Second Story Press.

Gibault, Thomas (2018). Hotel Fantastic. Toronto, ON: Kids Can Press.

Green, Lesley-Anne (2018). Fox and Raccoon. Toronto, ON: Tundra Books/Penguin Random House.

Henderson, Judith (illustrated by T. L. McBeth) (2018). Big Words Small Stories: The Missing Donut. Toronto, ON: Kids Can Press.

Hughes, Susan (illustrated by Carey Sookocheff) (2018). What Happens Next. Toronto, ON: Owlkids Books.

Hutchins, Hazel \& Herbert, Gail (illustrated by Lil Crump) (2018). Anna at the Art Museum. Toronto, ON: Annick Press.

Hyman, Zachary (illustrated by Joe Blum) (2018). The Magician's Secret. Toronto, ON: Tundra Books/Penguin Random House.

Katz, Andrew \& Léveillé-Trudel, Juliana (illustrated by Joseph Sherman) (2018). How to Catch a Bear Who Loves to Read. Montreal, QB: Crackboom Books. 
Kerrin, Jessica Scott (illustrated by Qin Leng) (2018). The Better Tree Fort. Toronto, ON: Groundwood Books/House of Anansi Press.

Larsen, Andrew (illustrated by Sandy Nichols) (2018). The Bagel King. Toronto, ON: Kids Can Press.

Little, Jean (illustrated by Joe Weissmann) (2018). Harry's Hiccups. Victoria, BC: Orca Book Publishers.

*Luby, Brittany (illustrated by Michaela Goade) (2019). Encounter. Toronto, ON: Tundra Books/Penguin Random House.

Luxbacher, Irene (2018). Deep Underwater. Toronto, ON: Groundwood Books/House of Anansi Press.

Maclear, Kyo (illustrated by Kenard Pak) (2017). The Fog. Toronto, ON: Tundra Books/ Penguin Random House.

Matthews, Gail (illustrated by Ali Hinch) (2019). Simonie and the Dance Contest. Iqaluit, NU: Inhabit Media.

Messier, Mireille (illustrated by Gabrielle Grimard) (2019). Nutcracker Night. Toronto, ON: Pajama Press.

Messier, Mireille (illustrated by Irene Luxbacher) (2019). Treasure. Victoria, BC: Orca Book Publishers.

Munsch, Robert (illustrated by Michael Martchenko) (2018) Moving Day! Toronto, ON: Scholastic Canada.

Nielsen, Susin (illustrated by Olivia Chin Mueller) (2019). Princess Puffybottom and Darryl. Toronto, ON: Tundra Books/Penguin Random House.

O'Leary, Sara (illustrated by Jacob Grant) (2018). Owls are Good at Keeping Secrets: An Unusual Alphabet. Toronto, ON: Tundra Books/Penguin Random House.

Ohi, Ruth (2018). Fox and Squirrel Help Out. Toronto, ON: North Winds Press/Scholastic Canada.

Ohi, Ruth (2019). No Help Wanted! Toronto, ON: North Winds Press/Scholastic Canada. Oldland, Nicholas (2018). Hop into Bed! Toronto, ON: North Winds Press/Scholastic Canada.

Orbie (2019). The Clothesline. Toronto, ON: Owlkids Books.

Renaud, Anne (illustrated by Leanne Franson) (2019). Emma's Gems. Winnipeg, MN: Peanut Butter Press.

Rust, Kari (2019). The House at the End of the Road. Toronto, ON: Owlkids Books.

Schwartz, Joanne (illustrated by Isabelle Malenfant) (2018). Pinny in Fall. Toronto, ON: Groundwood Books/House of Anansi Press.

Schwartz, Joanne (illustrated by Sydney Smith) (2017). Town Is by the Sea. Toronto, ON: Groundwood Books/House of Anansi Press.

*Smith, Monique Gray (illustrated by Danielle Daniel) (2017). You Hold Me Up. Victoria, BC: Orca Book Publishers. 
Smith, Sydney (2019). Small in the City. Toronto, ON: Groundwood Books/House of Anansi Press.

Sparrow, Kerry Lyn (illustrated by Guillaume Perreault) (2018). Sleep, Sheep! Toronto, ON: Kids Can Press.

Sparrow, Kerry Lyn (illustrated by Yinfan Huang) (2019). The Couch Potato. Toronto, ON: Kids Can Press.

Spires, Ashley (2019). Fairy Science. Toronto, ON: Tundra Books/Penguin Random House.

Spray, John (illustrated by Mies van Hout) (2019). What Cats Think. Toronto, ON: Pajama Press.

Storms, Guy \& Storms, Patricia (illustrated by Milan Pavlović) (2019) Moon Wishes. Toronto, ON: Groundwood Books/House of Anansi Press.

Sylvester, Kevin (2019). Gargantua (Jr!): Defender of Earth. Toronto, ON: Groundwood Books/House of Anansi Press.

*Tenasco, Sunshine (illustrated by Chief Lady Bird) (2019). Nibi's Water Song. Toronto, ON: North Winds Press/Scholastic Canada.

Tsiang, Sarah (illustrated by Sonja Wimmer) (2018). Sugar and Snails. Toronto, ON: Annick Press.

Valério, Geraldo (2018). Blue Rider. Toronto, ON: Groundwood Books/House of Anansi Press.

Walters, Eric (illustrated by Carloe Liu) (2019). Always With You. Halifax, NS: Nimbus Publishing.

Wang, Holman (2019). Great Job, Mom! Toronto, ON: Tundra Books/Penguin Random House.

Wilson, Troy (illustrated by Clayton Hanmer) (2019). Dog vs. Ultra Dog. Toronto, ON: Owlkids Books.

Wishinsky, Frieda (illustrated by Emma Pedersen) (2019). Alfie, No! Toronto, ON: North Winds Press/Scholastic Canada. 